\title{
Clothing the Other: The Use of Fashion in Pursuit of a British Imperial Utopia
}

\author{
Ibtisam Ahmed
}

\begin{abstract}
The British Raj provides a deep and rich case to study the implementation(s) of real-world political utopias. It fits with the definition of political utopian theory wherein the system was a reactionary attempt to solve contemporary systemic problems. As an imperial project aimed at civilising the native population and creating a good life for both them and the British officials stationed there, it is an embodiment of the utopian quest for an ideal and perfectible society. In this paper, the author examines how this attempt at utopia extended into the private sphere through the impact the British Raj had on gender through clothing. Gender was specifically seen as an embodiment of cultural, national, and even religious values, which provided a powerful tool for a narrative of the colonial Self against the pre- or anti-colonial Other. Clothing is a powerful inherent representation of identity and the narrative of the Raj, as well as the counter-narrative of independence, relying heavily on shaping notions of masculinity and femininity by controlling acceptability in clothing.
\end{abstract}

Keywords

Political utopianism, history, Empire, colonialism, gender

On the author's first trip to the Victoria \& Albert (V\&A) Museum in London a decade ago, he distinctly remembers the unusual feeling of looking at traditional South Asian clothing from a fetishizing gaze. The author is Bangladeshi himself, and the flowing silhouettes and bright colours are neither extraordinary nor unfamiliar to him. Yet, viewing these ordinary objects as cultural artefacts - and not just because the items in question were from a different time period-made the author consciously reflect on the fact that clothing has a distinct influence on the perceptions of culture, heritage, and social norms.

Ten years on, the author is now working on a project which examines the extent to which the British $\mathrm{Raj}^{1}$ can be studied as an attempt at political utopia, and the interest that was piqued at the V\&A has not abided. If anything, it has been enhanced by a deeper understanding of South Asian history and the legacy left behind by Empire. An important part of this is how imperial ideology was enacted not just through formal methods such as legislation, but also in how the private sphere was challenged and subverted. This extends to the subtle policing of gender roles that has been enacted for over a century now with the use of clothing and fashion.

In this paper, the author looks at how clothing was used as a tool of "Othering" traits that were deemed

aUniversity of Nottingham, Nottingham, UK

\section{Correspondent Author:}

Ibtisam Ahmed, Law and Social Sciences Building, University Park, University of Nottingham, Nottingham NG7 2RD, UK 
deviant or unwanted by examining the items on display in the South Asia wing of the V\&A in conjunction with scholarly work on gender and identity. The author will preface this analysis by looking at how primary written sources show the ways in which gender was perceived by the British colonisers and by the local population, in order to provide an ideological and cultural context for his first-hand descriptions and interpretations of the clothing in question.

\section{EMPIRE AND THE RHETORIC OF CIVILISATION}

That imperialism is a strategic system of territorial and economic conquest, is something that is easily understood, but in order to appreciate the extent to which it was able to permeate into the daily life of its inhabitants, it must also be approached from an ideological level. The crux of Empire and its justification lies in its projection as a civilising project (Spurr 1993; Hall 2002) aimed at creating a good or better life for its subjects-both colonisers and colonised. This carried an intentional aim at systemically changing socio-political structures within the territories of the Empire. In the British Raj, this intentionality extended to cultural norms as well as more formal institutionalised arenas such as government and law-making.

Speeches and writings of British officials show how their implementation of Empire as a civilising project incorporated critiques of and changes to both the private and public spheres. The excerpts here are taken from a collection of speeches on Indian policy archived by A. Berriedale Keith (1922). In a speech to Parliament, Thomas Babington Macaulay explicitly says that India was in a state of turmoil before the British arrived under the East India Company:

In what state, then, did we find India? And what have we made India? (...) At Delhi, as at Ravenna, there was a mock sovereign, a mere pageant immured in a gorgeous state prison. He was suffered to indulge in every sensual pleasure. He was adored with servile prostrations. (...) All the evils of despotism, and all the evils of anarchy, pressed at once on that miserable race. They knew nothing of government but its exactions. Desolation was in their imperial cities, and famine all along the banks of their broad and redundant rivers. It seemed that a few more years would suffice to efface all traces of the opulence and civilization of an earliest age. (Macaulay 1833)

The references to pageantry, sensuality, and opulence are not simply hyperbolic exaggerations; part of the sense of imperial superiority stemmed from a belief that better governance and better civilisation were a result of a detached, chaste, and impersonal rule of law that separated physical intimacy from power. By contrast, the rest of the speech upholds British values as a cure for these problems:

(Looking at British rule), I see scarcely a trace of the vices which blemished the splendid fame of the first conquerors of Bengal. I see peace studiously preserved. I see faith inviolably maintained towards feeble and dependent states, I see confidence gradually infused into the minds of suspicious neighbours. I see the horrors of war mitigated by the chivalrous and Christian spirit of Europe. I see examples of moderation and clemency, not debauchery, such as I should seek in vain in the annals of any other victorious and dominant nation. (...) I see a government anxiously bent on the public good. Even in its errors I recognize a paternal feeling towards the great people committed to its charge. I see toleration strictly maintained. Yet I see bloody and degrading superstitions gradually losing their power. I see the morality, the philosophy, the taste of Europe, beginning to produce a salutary effect on the hearts and understandings of our subjects. I see the public mind of India, that public mind which we found debased and contracted by the worst forms of political, religious and sensual tyranny, expanding itself to just and noble views of the end of government and the social duties of man. (Macaulay 1833)

This excerpt clearly shows how an openness to gender and sexuality—described as "debauchery" and "sensual tyranny"-is directly equated to a flawed society that can be fixed by adhering to a virtuous form of Christian morality. An earlier speech by Lord 
William Bentinck on the suppression of sati (self-immolation of widows on their husbands' funeral piers) not only criticises the practice for being "outdated" but further states that "the Hindu population needs to be enlightened as to their hedonistic outlook to life" (Bentinck 1829).

Following the transfer of British rule from the East India Company to the Crown in 1857 , the imposition of British values was formally taken up as part of imperial policy. A speech by George Cornewall Lewis when discussing taxation and the judiciary suggests that "these effeminate Bengalis need to be shown the way for their own good" (Lewis 1858). A letter by Queen Victoria to Lord Salisbury in 1898 concerning the new choice of Viceroy for India states that the native population must not be suppressed but must still be reminded of their place in society:

"He must be more independent, must hear for himself what the feelings of the Natives really are (...) They must of course feel that we are masters" (Victoria 1898).

Travel writings from the time show a similar sense of distaste towards Indian customs, with an implication that they either needed to be corrected or admired as exotic remnants of a quaint way of life. Kipling's self-professed "charity (...) towards those poor devils" and Forster's "disgust (at the) incoherent" local customs reflect an implicit view that anything not British was automatically inferior (works cited in Spurr 1993: 104).

In a series of letters written to her sister from 1837 to 1840, Emily Eden, the wife of the then Governor-General, noted how the differences between British and Indian lives manifested in deeply personal and intimate ways, and that any political attempts to reconcile the two would have to take into account these different cultural contexts. Referring to relationships and romance, she wrote:

Our native servants look so unhappy. They hate leaving their families, and possibly leaving two or three wives is two or three times as painful as leaving one, and they cannot endure being parted from their children (...) How strange that they can be faithful to more than one person. (Eden 1837 [reprinted 1984])

Eden's writings are among the more accommodating when it comes to acknowledging differences in context. In most cases, the attitude towards Indian norms was that they needed to be redressed. Winston Churchill, when writing as a correspondent for the Daily Telegraph in 1897, by which time authority had transferred to the Crown, referred to the personal lives of the Muslim inhabitants of northern India as such:

Their habits are filthy; their morals cannot be alluded to. With every feeling of if respect for that wide sentiment of human sympathy which characterises a Christian civilisation, I find it impossible to come to any other conclusion than that, in proportion as these valleys are purged from the pernicious vermin that infest them, so will the happiness of humanity be increased, and the process of mankind accelerated. (Churchill 1897)

Thus, based on documents from the time, it can be safely said that the imperial outlook towards Indian culture was not particularly positive. This outlook then shaped the ways in which Empire sought to change the region.

\section{PERFORMATIVE IDENTITY IN SOUTH ASIA}

The imperial rhetoric regarding Indian socio-cultural norms did not occur in a vacuum but was a reactionary response to what was perceived as being immoral. The sources cited in the previous section clearly show a negative attitude, but only the colonisers' approach to identity. In order to fully understand how their policies and rhetoric were aimed to counter existing narratives, those native narratives need to be looked at as well. It is impossible to provide a detailed look at all the key texts from the area within one article, as 
was done in Readings From Literature and History: Same-Sex Love in India (Vanita and Kidwai 2000)-book that provides full texts in translation along with historical contexts and brief analyses. Instead, the author hopes to provide a broad overview of the largely tolerant approach to gender identity by looking at texts from different periods, regions, and religions within pre-colonial South Asia, providing a wider context for the excerpts chosen. The texts in question are all translations that have been collected by Vanita and Kidwai in their work.

Texts from various periods show that the religious approach to gender in Hinduism was one which viewed it as both performative and lived - which is to say that an individual's identity was seen as a composite of physiological aspects such as sex organs and how the individual embodied certain traits and characteristics. Gender was therefore not understood as a static dichotomy between male and female, but a fluid spectrum that moved between the two. Many texts also supported same-sex intimacy and romance, which, once again was in direct contrast to the moral views later imposed by imperial policy.

The section on "Sikhandin's Sex Change" in the Mahabharata recounts how the titular character was born to a king who desperately wanted a son, even though he was fated to have a daughter. The gods promised him a female-male; Sikhandin was born as a girl but raised as if she was a prince, learning archery, combat skills, writing, and other arts. When the time came for her to be married, her parents wooed another princess on her behalf - again, choosing to treat her as a son rather than a daughter.

When the betrothal was confirmed and Sikhandin was revealed to her fiancée's father, he felt insulted at being lied to and threatened war. However, the gods intervened and, upon reflecting of the virtuous life of Sikhandin and the way that she was raised, bestowed on her the physical appearance of a man to complement her inner self. The chapter concludes with this paragraph:
This is how (...) Sikhandin, the excellent charioteer, the son of Drupada, was born a woman-man. O bull of the Bharatas was born in Drupada's family as Sikhandin. If he approaches me, armed with the bow, to fight, I will not even look at him for a moment, nor hit him. (Translated from the Sanskrit original by DasGupta and Kidwai)

The use of the words "he" and "him" is telling here as they reflect that Sikhandin-referred to as "she" earlier in the text- has truly changed by the end of the section. There is still a challenge to the notion of same-sex intimacy here, as shown by the unwillingness of the fiancee's father to allow the wedding to go through as is, but Sikhandin's gender identity is divinely sanctioned and protected, showing that the discriminatory judgement made by humans is wrong. Moreover, the divine endorsement of Sikhandin's maleness stems not from their physiology but in the ways they lived their life-raised with the same knowledge and skills that would be taught to a prince-indicating that identity is more complex than a simple superficial understanding.

Other texts explicitly state that gender is not simply a case of being born male or female. In the Kamasutra, there is a clear understanding that an individual's gender identity is determined by how they present themselves rather than their genitalia. Specifically, chapter nine mentions the following:

The ones who take the form of women have breasts and long hair while the ones who take on the form of men have moustaches and beards. These may or may not be natural. It is in the behaviour of the individual, in their dress, their adornments, manner, tone of voice, sweetness, timidity and shyness, or firmness and strength, that one can see their nature of female or male. (Translated from the Sanskrit original by DasGupta)

Taking this a step further, the text addresses same-sex intimacy as well by pointing out that men who have sex with men are more distinct in appearance and behaviour than women, thus dissociating notions of femininity from homosexuality, and clearly delineating the difference between a man 
who performs or lives as a woman ${ }^{2}$-including both permanent male-to-female transitions and temporary ones such as dancers or actors in a role-against a man who desires other men.

Both the Mahabharata and Kamasutra are ancient texts, but their approaches to performative gender are reflected in much later writings as well, including those taken in the early years of the British Raj. The oral testimonies of Shri Ramakrishna contain a section where he reveals how, in 1879, he "yearned deeply for a young male disciple" and then "approached him dressed as a woman, but with the full revelation of who (he was) and (he) was accepted in that moment as (his) feminine self" (translated from the original by Vanita).

Another text is the Bengali Indira, a novella published in 1873. The titular Indira is a woman who has a deeply passionate and physical relationship with another woman, Suhbashini, but it is not until she is dressed in feminine garbs that they go ahead with their intimacy:

She wiped my face clean. Then, having massaged my hair with fragrant oil, she started to tie my hair into a chignon (...) She then took one of her own clean and beautiful saris and started to drape it around me (...) she proceeded to take mollika (jasmine) flower buds from a jardinière and made me wear bracelets, anklets and a necklace of these buds. Then, she produced a brand-new pair of golden earrings. (Translated from the original by Ghosh)

Unlike the section in the Mahabharata, where gender is subverted through dress in order to legitimise the heterosexuality of a relationship, Indira reinforces gender roles and highlights the femininity of a female character in order to strengthen a homosexual relationship. In both cases, it is the performance of the gender through a physical embodiment that validates it.

Texts in the Islamic tradition also support the performativity of gender, although the interpretation of it leans towards a temporary embodiment of a different gender identity, rather than a permanent transition (Banerji 2008). The Urdu narrative poem Bustain-I Khayal, written in 1738 by Siraj Aurangabadi, includes a description of how his "beloved spent days and hours with (him), and (they) would take turns dressing as the woman so that (they) may be an ordinary couple despite (their) extraordinariness" (translated from the original by Kidwai). Whether the use of the word "ordinary" implies that same-sex intimacy is viewed pejoratively or not in this context is difficult to verify or deny. What can be said more confidently is that the outward appearance and presentation of femaleness for either one of the couple is enough to fit in with standards of normality.

Another Urdu poem, Abru: Advice to a Beloved, includes the following couplets that touch on appearance and presentation:

If you wear a turban, wrap it carefully-Untie and tie a hundred times if need be

A perfect fit, matching shades, none clashing, A long kurta, creased at the wrist, looks dashing.

Dressed in such style, enter any room Like a garden in full springtime bloom.

Swaying as you walk is an attraction, Don't overdo it-all things in proportion!

If you enjoy mincing, swaying, prancing, Do it in a way that proves entrancing.

Even sitting down can be an art-Sit delicately, grace in every part. (Translated from the original by Kidwai)

In this case, clothing such as the turban and the kurta, is traditionally male or masculine, but the reference to entering a space as if a flower, and the subsequent descriptions of behaviour, may be understood as traditionally female or feminine. This is slightly more complicated than a single notion of performativity - wherein the dress and the behaviour match up to the same type of gender identity regardless of physiology - as the two aspects of presentation seem to be in conflict. What this underlines is that the performativity of gender did not 
simply mean embodying either a masculine or feminine nature at any given time, but that both natures could co-exist at the same time. Rather than a point against identity as fluid, this text best supports the assertion by Vanita (2002) and Banerji (2008) that the pre-colonial understanding of gender in South Asia was one which depended on a multitude of factors, rather than being the rigid binary of colonial ideology.

\section{CLOTHING AND GENDER}

Having looked at how gender was seen as a performative act in literature, it is important to extend that understanding into the material world and real bodies. The body in the British Raj was a politically charged space because it was a living representation of this identity and its associated ideals. By being a visual indicator of conformity, or the lack thereof, it became a powerful means of reinforcing the civilising ideology at the heart of the imperial project, an ideology which represented a move towards a utopian good life (Collingham 2001).

Symbols of the native body and its autonomy were a direct contradiction to the supposed supremacy of anglicised morality and values. By the time the Crown took control of the Raj in 1857, the British perception of gender was one where roles and norms were rigidly defined and projected as a male-female binary (Spurr 1993), while texts from even the early years of the Raj showed that this was not the case in the subcontinent. While traditional roles for men and women did exist in most parts of the Raj-such as militancy being equated to maleness and peace-keeping to femaleness-negative perceptions of gender, masculinity, and femininity, and an unwavering definition of acceptable desire did not exist (Collingham 2001; Nicol 2014).

In order to create a unified colonial Self that could be used as a utopian blueprint for acceptability, an undesirable Other had to be conceptualised as a counter-point against which the Self could be held up. This Self/Other relation creates a path to attain perfectibility by framing certain actions and/or individuals as (part of) the problem. In doing so, it implies a solution to the said problem by punishing the Other in order to protect or strengthen the Self (de Groot 2000; Stepan 2000). Gender, especially through clothing, was a natural choice for this dynamic to be played out because it was already conceptualised differently by the colonisers and the colonised.

The V\&A archives provide a revealing glimpse into the style of clothing that was common in different parts of what became the Raj in the period immediately preceding British rule. Courtly dress, especially in Muslim royal courts such as those of the Mughals, had similar style lines for both men and women. The jama (top) was always knee-length, with long sleeves, intricate embroidery, and a flared-out bottom half from just below the chest area. The pajama (literally, foot-jama; bottom) was traditionally loose-fitting to allow for ease of movement and sitting down. Regional variations aside, such as the predominance of certain colours or fabrics, and the volume of sleeves or of the flared bottom half of the jama, this silhouette was common to nearly all the states and kingdoms in the region, including Bengal, Oudh, Delhi, Rajputana, the Punjab, Kashmir, and across what is now central India, and could be worn by both men and women. In specific regions, women would usually wear a long piece of wraparound cloth known as a sari, which men did not wear, but the standard silhouette for separates was universally androgynous, with the difference being that men would wear caps or go bare-headed while women would wear a shawl (Crill 2015).

Both men and women also wore necklaces and rings, with men usually having larger pieces and women having more intricate ones. Men wore turban and arm ornaments, while women had a range of hair ornaments, ear rings, and nose rings. In the wealthier social strata, jewellery was made of fine metals and 
gems and worn regularly, but individuals in the lower strata also had similar styles made from earthenware and cheaper metals to be used in religious ceremonies and on special occasions such as weddings or harvest festivals (Stronge 2016). Like clothing, styles and silhouettes for jewellery were largely androgynous.

An interesting example of how clothing was used to specifically highlight gender as a performative act was in the courtly ceremonies of the nawab (ruler) of Oudh, a princely state. The nawab was always male due to the patrilineal line of succession but, in order to represent his subjects more evenly, would spend specific fortnights in the year wearing a shawl instead of a cap, wearing female jewellery, being addressed using female pronouns, and even taking on a male consort. The sign that these fortnights would be commencing or ending came from the dress of the nawab, which acted as the cue for how they would then be addressed; the consort was largely for the private sphere and could not be used as a definitive marker of the nawab's gender identity at any given time (Nicol 2014).

The author should take a moment here to address what may be seen as a contradiction of the performativity that he mentioned in the previous section. All of the excerpts the author cited make specific references to presenting as either male or female based on paraphernalia such as clothing, but, as he has described here, many items of clothing were actually quite androgynous. Therefore, a legitimate challenge can be made to whether clothing could really have played such a strong role in performative gender if men and women wore similar styles to begin with.

The author's response consists of two parts. The first, which may seem purely pedantic, is that, while clothing was largely androgynous, specific items such as headgear and jewellery were distinct. This shows that clothing was not entirely devoid of gendered perceptions; rather, their gendering was more nuanced than overtly separate styles. The second point, which builds on the subtle gendering the author refers to in the first, is that the androgyny was what facilitated a smoother embodiment of gender as a transitionary and performative act. By removing rigidity in clothing, but by still having nuanced differences, it became easier for gender to be presented fluidly.

\section{RHETORIC OF THE EFFEMINATE IN THE AFTERMATH OF 1857}

The Crown took control of the Raj immediately after the end of the Sepoy Rebellion of 1857. Prior to this, the British East India Company was the ruling authority and representative of British interests in South Asia. Falling under the jurisdiction of Empire instead of simply being a controlled trading outpost meant that identity in the Raj needed to be reconfigured to fall into a single, or at least singular, narrative (Cohn 1996: 5-8). Due to the violent nature of the Rebellion, one of the most effective pieces of rhetoric used to create this identity was through demeaning and demonising certain aspects of the losing rebels' norms.

The military victory of the British forces during the Rebellion was not just attributed to superior armaments, resources, and strategy, but also extended to criticisms of "effeminate" natives and their lifestyles (McClintock 1995). The fact that the armour of the rebel forces imitated the androgynous silhouette of standard clothing (Crill 2015; Richardson and Bennett 2015) was highlighted and ridiculed (Sinha 1995: 150). Imperial artwork showing the key actors in the Rebellion consciously depicted British officials in positions of "masculine power" (Smith 2016: 102) while the Indian leadership was portrayed as "dainty (and) weak" (Corbeau-Parsons 2016: 132, 135). This rhetoric was made effective by the simple and undisputable fact that the British forces won. By tying in their military superiority with their perceptions of gender, they made the latter seem like a valid interpretation (Gott 2011). 
Two specific cases of this rhetoric being employed against gender practices and roles came in the form of targeting the rebel leadership. Among the rebelling states were Jhansi and Oudh, the former led by a rani (queen) and the latter by a nawab who ceremonially rejected gender roles. Jhansi's loss was partially attributed to the fact that its armed forces were led by a woman while the courtly practices of Oudh were not only criticised but actually made illegal under the Crown rule (Nicol 2014).

Once again, the V\&A archives show the effect of this rhetoric. In the period immediately after 1857 , there was already a distinct change in silhouettes. While the length of the jama was still to the knee, the flare of the bottom became less pronounced for men, with the overall shape becoming boxier and with straighter lines. The silhouette for women did not change much following the Rebellion, with the exception of the neckline becoming squarer, mimicking Victorian fashions and sensibilities regarding the bustier.

Over the following decades, these changes became even more pronounced, with a tilt towards Victorian inspirations being seen as a sign of wealth and/or superiority (Crill 2015: 11-12). The men's jama became shorter and eliminated any feature that was billowy or loose-fitting. Women's clothing, by contrast, extended to the foot, with ribbing and corseting in the upper half juxtaposing a free-flowing bottom half. Similarly, jewellery began to be seen as exclusively female, although male rulers still wore them when putting on ceremonial or courtly robes (Stronge 2016). Thus, clothing not only became a part of the imperial rhetoric through its ridicule of Indian armour and styles, but then began to reflect the success of this rhetoric by changing to fit British norms.

\section{CLOTHES, AUTHORITY, AND SUBORDINATION}

Indian clothing had a history of being culturally identified as part of the "Other" by the British even before the Crown took over. In 1830, the wearing of Indian styles of dress in public functions by East India Company officials was banned (Cohn 1996). However, there were no attempts to regulate clothing for the native population until after 1857. Unlike the Company ban on clothing, this was not done through legislation or formal policy, but by irrevocably entwining clothing with the rhetoric surrounding gender norms and its subsequent subtle impact.

One of the key factors in this was in delineating markers of control. Under both Muslim and Hindu rule, monarchs - a suitable substitute term for the variety of local words used to mean king, queen, or the equivalent - were the embodiment of authority, not just in their ability to make and enforce laws, but also in the way they presented themselves. Although the British Crown had its symbolic equivalent in Victoria (and, indeed in Britannia), the actual holders of power as seen by the Indian populations were always white British men. The Viceroy of India and all high-ranking members of his administration were male and this served to create a homogeneous representation of what power was supposed to look like (Cohn 1996: 113-115).

Further highlighting this was the role of British women. While men and masculinity were actively associated with power and control, women and femininity became representations of an idealised domesticity that was centred on family life, housekeeping, and occasionally, charity. Men had official, formal, and casual clothing, but their wives and daughters - it was extraordinary for an unmarried woman to travel to India without a male family member in tow - generally had only one type of dress (Cohn 1996: 115-116).

This domesticized and dependent nature of British women under Crown rule represented a shift away from the role of the missionary women under the East India Company before 1857. The religious drive of Christian missionaries included recruiting single 
women to travel to outposts of the Empire in order to present a softer and more approachable contrast to the military wings that consisted solely of men. However, once the Raj was officially formed in 1857, the supreme authority of the Crown meant that there was no longer a concerted need for missionary work as a means of exerting influence. Therefore, the role of British women changed (Cook 1996: 124-126). Interestingly, this change not only meant that the representation of acceptable femininity took on an exclusively domestic outlook, but it also meant the agency of British women became limited as well. Thus, traditional femininity was not only seen as soft and domestic, but it was also made clearly inferior to corresponding notions of masculinity (Midgley 1998: $15)$.

Under Victorian Crown rule, the silhouettes for British women's clothing were comparatively closer to Indian clothing than those of British men. Therefore, the links between them and the level of control became part of an unspoken discourse in the manifestation of an imperial utopia. In particular, the ceremonial clothing worn by Indian rulers, who became vassals under imperial protection and patronage, became an identifier of them being subordinates assigned to a form of political domestic upkeep under the authority of a male British ruling class.

\section{DEVIANT BODIES, SUBVERSIVE ACTS, AND A NEW UTOPIA}

The utopian ideal of a segregated and clearly demarcated male/female dichotomy was largely successful in its implementation. The items of clothing in the V\&A archives post-1900, especially in the 1910's and early 1920's, show how male silhouettes actually became completely anglicised, with traders, lawyers, judges, academics, political figures, and university lecturers preferring to wear suits and ties. Having a tailored suit from Saville Row became a mark of status. Women continued to wear traditional silhouettes, but Western influences were still seen in the print patterns as well as in jewellery. Where local kundan enamelling had been highly sought after items in the nineteenth century, Western brands like Cartier and Harry Winston became the new standards of luxury (Stronge 2016). Nonetheless, there were still continued pockets of dissent that used clothing to create a narrative that rejected the idea of an imperial utopia.

The most visible objection came from the Hijra community. Using modern terminology to define Hijra is difficult. While some may erroneously conflate them with being transgender only, the community has a longer-standing history of being subversive in its presentation and understanding of gender, with the closest definition using modern LGBTQ+ terms being a mixture of intersex and transgender women, as well as gender-fluid and genderqueer individuals who present female. The community existed in various parts of the subcontinent as a distinct part of society even before the arrival of the British under the East India Company. Hijra would live and dress as females and would occupy specific roles in certain ceremonies such as weddings and funerals. Parents unwilling to raise intersex children would willingly let the Hijra community adopt them. It is unclear whether the modern stigma associated with being Hijra and the highly cloistered nature of their housing existed before the British; sources that refer to Hijra such as verses in the Kamasutra simply make a note of their existence without any judgement for or against their identity (Baudh 2013).

What is clear, however, is that the community faced particular scorn from British officials. Their long-standing place in society prevented any form of prosecution or criminalisation for being Hijra, but they were nonetheless openly derided for failing to meet the standards for the hegemonic gender roles imposed by Empire (Banerji 1998). While the 
community did not take part in any formalised anti-imperial movements such as protests or rallies, as became commonplace in wider Indian society in the twentieth century, their very existence and continuous use of female clothing was a direct subversion of the utopian ideal that was being imposed by the British.

A similar instance of local traditions being used to undermine British imperial superiority was in the arts. Theatre productions continued to use traditional Indian silhouettes, including when adapting British plays to the stage such as the works of Shakespeare. The practice of cross-dressing on stage became a quiet but powerful political act that stood in defiance of strict gender norms. Indian classical dance performances also undermined the male-female dichotomy as the story-telling aspect of the dance styles meant that the performer would embody male and female roles at various times on stage (Cook 1996). In fact, theatre and dance were such strong visual representations of Indian identity that, when the anti-imperial movement began to turn into a universal call for independence, cultural performances, including the nuances of costume, were used as preludes to speeches during political rallies (Tagore 1918 [reprinted 2009]).

As a counter-narrative to the idea of an imposed British utopia, an organic and grassroots utopia that focused on Indian traditions became the new standard of the independence movement. One of the most successful aspects of this was the use of clothing by its leadership. Much of the leadership, including Jawaharlal Nehru and Mohandas Gandhi, had been educated in Britain and took to wearing Western clothing when dealing with other political operatives and with British officials. Part of this stemmed from the belief that negotiating with the British on their terms would prove to be more successful.

However, the increasing rejection of Indian demands for autonomy and respect, combined with the lack of support for the region during World War I despite the number of Indian soldiers who went to war and incidents like the Jallianwala Bagh Massacre, led to widespread disillusionment amongst the political elite. Nehru began to wear a distinctive kurta and pa-jama combination in all public events, including when meeting foreign officials (Crill 2015).

Gandhi took it a step further, renouncing not only British silhouettes but also British textiles. The khadi movement became one of the most iconic forms of anti-imperial protest. Khadi is a type of hand-spun cotton that was and continues to be common across South Asia. Gandhi utilised it as a political tool, instructing fellow Indians to spin their own khadi by hand as a means to both reclaim their heritage and also contribute to a self-sustaining local economy that could survive without British imports (Mawby 2015). His choice of clothing - a dhoti made from hand-spun khadi-was a clear statement against British ideology because it subverted the dress code expected from political figures. This clearly angered key British politicians:

"It is alarming and nauseating to see Mr Gandhi, a seditious Middle Temple lawyer, now posing as a fakir (...) striding half-naked up the steps of the Vice-regal Palace" (Churchill 1931).

Clothing had been used for decades as a way to impose the cultural aspect of a British good life. When that utopia was challenged, it was inevitable that clothing would once again become a representation of the counter-narrative. While this new movement did not necessarily challenge the established British gender norms, it is important to remember that the act of spinning khadi could be done equally proficiently by men and women, and was a powerful way to bring domesticized femininity back into the political arena.

\section{CONCLUSIONS}

Clothing and fashion are not simply manifestations of taste and wealth, but can be used as part of wider attempts at shaping the political landscape. Indian clothing prior to the Raj had been androgynous in 
style and silhouette, which reflected a fluid approach to gender identity, sexuality, and individual morality.

When the Crown wanted to implement its vision of a utopian good life, its civilising mission had to extend beyond simple policy and legislation. Clothing was one of the areas which was directly influenced as a way to redefine gender to fit with a Victorian understanding of a masculine/feminine dichotomy. When this utopia was later challenged by a different vision of the ideal life - one of an independent India with a reclaimed culture - clothing once again became a potent political weapon.

Tracing the evolution of styles can, therefore, be a rewarding way to recollect various histories in culture and politics. The author's observations of the V\&A collections are just one part of this extremely rich field of study. Areas the author has not explored include the differences among rural, urban, and tribal fashions, and how clothing and its politics were different between economic classes. Nonetheless, the narrative in the author's paper provides an inroad into a much more nuanced case and, hopefully, can be the starting point for further discussions and research.

\section{Acknowledgements}

The field research at the V\&A is made possible by grants provided by the School of Politics and IR, the University of Nottingham, and by the Centre for the Study of Social and Global Justice (CSSGJ). CSSGJ and the Institute of Asia Pacific Studies (IAPS) also provided funding to present this paper at the Utopian Studies Society Conference held in Lisbon, Portugal on July 4-9, 2016. The author would like to express his gratitude to his supervisors, Professors Lucy Sargisson and Steven Fielding, the participants at the conference for their invaluable feedback, and Zorian Clayton and the V\&A LGBT Research Network for their support.

\section{Notes}

1. Specifically referring to the time in which British India was under direct Crown Rule and not under the authority of the British East India Company. As such, the time period in question refers to 1857 until 1947.
2. A disclaimer is necessary here to acknowledge that this characterisation is highly problematic in the modern understanding of transgender and non-binary identity, but is made with regards to respecting the spirit and context of the original text which was written in the second century $\mathrm{BC}$.

\section{References}

Banerji, H. 1998. "Age of Consent and Hegemonic Reform." Pp. 21-44 in Gender and Imperialism, edited by C. Midgley. Manchester: Manchester University Press.

Banerji, R. 2008. Sex and Power: Defining History, Shaping Societies. London: Penguin Books.

Baudh, S. 2013. "Decriminalisation of Consensual Same-Sex Sexual Acts in the South Asian Commonwealth: Struggles in Context." Pp. 287-312 in Human Rights, Sexual Orientation and Gender Identity in the Commonwealth: Struggles for Decriminalisation and Change, edited by C. Lennox and M. Waites. London: Institute of Commonwealth Studies.

Bentinck, W. 1829. "Discourse on Sati." Speech delivered to the House of Commons, London.

Churchill, W. 1897. "Letter of Opinion." Daily Telegraph. London.

- 1931. "Address to Council." Speech delivered to the Council of the West Essex Unionist Association.

Cohn, B. S. 1996. Colonialism and Its Forms of Knowledge: The British in India. Princeton: Princeton University Press.

Collingham, E. M. 2001. Imperial Bodies. Cambridge: Polity Press.

Cook, S. B. 1996 Colonial Encounters in the Age of High Imperialism. New York: Longman Press.

Corbeau-Parsons, C. 2016. "Power Dressing." Pp. 124-149 in Artist and Empire, edited by A. Smith, D. B. Brown, and C. Jacobi. London: Tate Publishing.

Crill, R. 2015. The Fabric of India. London: V\&A Publishing. de Groot, J. 2000. "'Sex' and 'Race': The Construction of Language and Image in the Nineteenth Century." Pp. 37-60 in Cultures of Empire: A Reader, edited by C. Hall. Manchester: Manchester University Press.

Eden, E. (1837-1840) 1984. Up the Country: Letters From India. London: Virago Travels.

Gott, R. 2011. Britain's Empire: Resistance, Repression and Revolt. London and New York: Verso.

Hall, C. 2002. Civilising Subjects: Metropole and Colony in the English Imagination 1830-1867. Cambridge: Polity Press.

Keith, A. B. 1922. Speeches on Indian Policy. Vol. I. Oxford: Oxford University Press.

Lewis, G. C. 1858. "Taxation and Judiciaries in Bengal." Speech delivered to the House of Commons, London.

Macaulay, T. B. 1833. "Government of India." Speech 
delivered to the House of Commons, London.

Mawby, S. 2015. The Transformation \& Decline of the British Empire: Decolonisation After the First World War. London and New York: Palgrave MacMillan.

McClintock, A. 1995. Imperial Leather: Race, Gender and Sexuality in the Colonial Contest. London and New York: Routledge.

Midgley, C. 1998. "Introduction: Gender and Imperialism: Mapping the Connections." Pp. 1-20 in Gender and Imperialism, edited by C. Midgley. Manchester: Manchester University Press.

Nicol, N. 2014. No Easy Walk to Freedom. Ontario: Envisioning Global LGBT Human Rights.

Richardson, T. and N. Bennett. 2015. Indian Arms and Armour. Leeds: Royal Armouries.

Sinha, M. 1995. Colonial Masculinity: The "Manly Englishman" and the "Effeminate Bengali" in the Late Nineteenth Century. Manchester: Manchester University Press.

Smith, A. 2016. "Imperial Heroics." Pp. 84-123 in Artist and Empire, edited by A. Smith, D. B. Brown, and C. Jacobi. London: Tate Publishing.

Spurr, D. 1993. The Rhetoric of Empire: Colonial Discourse in Journalism, Travel Writing, and Imperial Administration.
Durham and London: Duke University Press.

Stepan, N. L. 2000. "Race, Gender, Science and Citizenship." Pp. 61-86 in Cultures of Empire: A Reader, edited by C. Hall. Manchester: Manchester University Press.

Stronge, S. 2016. Bejewelled Treasures: The Al Thani Collection. London: V\&A Publishing.

Tagore, R. (1918) 2009. Nationalism. Noida: Penguin Books India.

Vanita, R. and S. Kidwai, eds. 2000. Readings From Literature and History: Same-Sex Love in India. London and New York: Palgrave MacMillan.

Vanita, R., ed. 2002. Queering India: Same-Sex Love and Eroticism in Indian Culture and Society. London and New York: Routledge.

Victoria. 1898. Letter to Lord Salisbury.

\section{Bio}

Ibtisam Ahmed, doctoral research student, School of Politics and International Relations, University of Nottingham, Nottingham, UK; research fields: critical utopian theory, imperialism and historiography, queer theory, BME studies, politics of culture. 